The preprint shown in the next pages is accessible according to the license CC-BY-NC-ND. After peer-review, a new slightly revised and formatted version was accepted for publication, and is available here: https://doi.org/10.1016/j.jclepro.2021.126015

Silvio Cristiano,

Organic vegetables from community-supported agriculture in Italy: Emergy assessment and potential for sustainable, just, and resilient urban-rural local food production,

Journal of Cleaner Production,

Volume 292,

2021,

126015 ,

ISSN 0959-6526,

https://doi.org/10.1016/j.jclepro.2021.126015.

(http://www.sciencedirect.com/science/article/pii/S0959652621002353)

\title{
Organic vegetables from community-supported agriculture in Italy: emergy assessment and potential for sustainable, just, and resilient urban-rural local food production.
}

\author{
Silvio Cristiano ${ }^{\text {abc }}$ * \\ ${ }^{a}$ Università Ca' Foscari Venezia, Department of Environmental Sciences, Informatics and Statistics, Mestre, Venice, Italy. \\ b Università Ca' Foscari Venezia, Department of Molecular Sciences and Nanosystems, Mestre, Venice, Italy. \\ ${ }^{\mathrm{c}}$ Università Ca' Foscari Venezia, Research Institute for Complexity, Venice, Italy. \\ Dr. Silvio Cristiano (silvio.cristiano@unive.it)
}

\begin{abstract}
Global crises such as the COVID-19 pandemic highlight the interconnectedness and vulnerability of human systems, requiring integrated interdisciplinary studies aimed at breaking unsustainable and unjust practices. In this work, a horticultural collaborative production system is addressed, inspired by the community-supported agriculture (CSA) model. In a highly industrialised area of Northern Italy, with significant wild land consumption, an alternative bottom-up experience is described for the provision of vegetables in a short and cooperative not-for-sale supply chain. Local organic farming and just labour conditions seek ecological sustainability and social equity beyond market dynamics. This CSA project contributes to the resilience of a territory currently affected by health and economic plights. Its claims, limits, and potentials of a project of this kind are investigated for the first time by means of the Emergy Assessment (EMA). The socio-ecological and economic inputs in the system at issue are identified and quantified, partly eased by the transparent process of the target community, and some key indicators are calculated. This EMA provides fruitful insights of a single replicable and/or scalable project, thus offering current barrier and future opportunities for local improvement and exportability to crisis and post-crisis scenarios, and anyway for pursuing sustainability goals.
\end{abstract}

\section{Keywords:}

Clean and Just Production; Local Food Systems; Resilient Cities; Emergy Accounting; Food Geographies; Emergy Analysis; Systems Thinking

\section{Introduction}

Food and agriculture play a direct or indirect role in each of the Sustainable Development Goals (SDGs) the United Nations (UN) set for 2030 (United Nations, 2015; FAO, 2020a). Still, the UN's High Level Political Forum (HLPF) and Food and Agriculture Organisation (FAO) are both warning that policies are currently "off track" worldwide to meeting such goals (FAO, 2020b). If this was already true immediately before the outbreak of the COVID-19 pandemic - with expectedly rising hunger and food insecurity, poor 
incomes for small-scale producers, and stagnant governmental spending on agriculture -, the related health, economic, and social crisis, which now threatens lives and livelihoods, makes the achievement of such targets even further challenging (ibid.). Claims are often reported (also by FAO officers: Maass Wolfenson, 2013) that smallholders would produce between $70-80 \%$ of the global food out of roughly one quarter of the available fertile land; a recent survey of $51 \%$ of crop production on Earth argues that farms under 2 ha yield $30-34 \%$ of the global food supply on $24 \%$ of gross cultivated area, with better performances in terms of post-harvest losses (Ricciardi et al., 2018). Nevertheless, when it comes to studies on farming, small producers are often underrepresented in scientific literature (see also Section 2.3). Parallel to this, urbanisation, fertile land consumption, and corporate agrobusiness all seem exhibiting increasing trends in recent years. In a similar perspective, food provision causes local and global environmental impacts (Wood et al., 2006); to reduce these impacts, one frequently proposed approach is organic farming, i.e. farming practices seeking long-term sustainability (ibid.). Gomiero et al. (2008) suggest that more research and funding would be needed to explore the potential of organic farming in reducing the environmental impacts of agricultural activities. If governmental sustainability policies are failing globally, as reported, interesting solutions seem to rather come from the bottom up (see e.g. Lyons et al., 2013; Purcell \& Tyman, 2015; Pellicer-Sifres et al., 2017; Scott et al., 2018; Nelson \& Edwards, 2021), also adderessing other paramount issues such as sufficiency and equity. The COVID-2019 pandemic reminds us and highlights that human systems are interconnected, vulnerable, and often unfair. This is why more integrated interdisciplinary studies would be required, aimed at finally overcoming unsustainable and unjust practices while getting prepared for the aftermath of such a global crisis. Among grass-root models and experiences, the interest is here focused on a format that is often recognised as one of the most advanced when talking about food production, for its merging the producer and the consumer roles (someone calls the resultant a "prosumer") and - above all - practicing food decommodification and mutualism in addition to seeking ecological sustainability (Cristiano et al., 2021): the Community-Supported Agriculture (CSA) (Lamb, 1994; Volz et al., 2016). CSA experiences seem able to simoultaneously address several spheres of sustainability, starting from the environmental and social aspects; the economic aspect is also pursued in what may be the original meaning of the term, i.e. ensuring enough food for all its members and adequate income to whom works more for the project. Out of profit-seeking dynamics, the merging parties of former producer and consumer share risks and benefits, and this might become an asset in times of crisis and uncertainty. In Gibson-Graham's (2006) diverse community economy iceberg, advanced CSA experiences can be placed at the bottom; similarly to another metaphorical iceberg - that of systems thinking (Meadows, 2008) - the submerged parts can offer more potential for change with less efforts, thus making a CSA a candidate leverage point for just and sustainable transformations (Cristiano et al., 2021). These peculiarities of bottom-up experiences tend to be mainly faced in urban studies, urban planning, human and politicaleconomic geography, and social sciences in general. This contribution aims at complementing the knowledge coming from such disciplines by means of a tool able to holistically and qualitatively grasp the systemic operations of a CSA project while also providing quantitative information about its overall requirements from the geobiosphere. The ultimate goal here is to explore the sustanability, resilience, and replicability potentials of a small-scale CSA experience for food production. Specifically, it intends to understand and illustrate (a) the key factors that can make (or not) a CSA venture sustainable and resilient; (b) the direct and indirect natural and economic resources needed, together with their size and implications when compared to other vegetable products; and (c) initial hints for their expected replicability and/or scaling-up to possibly provide clean and just food, while targeting the currently endangered food and agriculture-related SDGs.

\section{Materials and methods}

\subsection{Rationale for choosing Emergy Accounting}

The method is chosen due to its being at the same time a qualitative and a quantitative tool, providing an overview of the main functioning of a system and some information about the required resources, which are both crucial in medium- and long-term integrated sustainability and resilience assessments. In farming, most impacts usually happen off-farm (Wood et al., 2006), so it is important to directly and indirectly track back the quality and quantity of needed inputs. A systems ecological assessment is essential for a sound resource allocation in agriculture (Chen et al., 2006). Among the many investigations undertaken about the sustainability of farming systems, not all take biophysical aspects into consideration (Artuzo et al., 2020). Besides being a comprehensive approach, appropriate for sustainability (and - we may add - resilience) 
studies, emergy accounting allows to properly evaluate agricultural system, also permitting comparisons with each other and/or with themselves over time (ibid.). As recalled by Brown and Ulgiati (2004), farming was an important concern for the father of the emergy concept, Howard T. Odum, even before developing its seminal theories: indeed, while discussing energy and food matters to the USA's presidential Science Advisory Committee interested in world food supply, Odum (1967) proposed to begin "the process of quantifying the energy cost of energy by quantifying the fossil fuel energy required to produce food", suggesting that "there was roughly one calorie of fossil energy required per calorie of food delivered through modern agriculture". The "memory" of such fossil energy can be detected by what Odum will later formulate in the emergy concept and in the related emergy accounting (see Section 2.2). If using nonrenewable fuels can be financially rewarding in the short run, medium- and long-term issues are instead expected for the consequences of the depletion of a scarce resource and for its environmental and health-related effects (sustainability-oriented comment) and for the consequences in its provision in the system that right upon such resources were relying (resilience-oriented concern). If standard socio-economic evaluation approaches tend to favour large conventional agrobusinesses that may be cost efficient and financially independent, emergy accounting is instead suitable to more correctly address the assessment of smaller farms, including organic ones, usually exhibiting greater abilities to use free local resources, and to cause less stress onto their local environment (Jaklič et al., 2014). The latter virtues can be anyway seen as crucial for any study targeting medium- and longlasting integrated sustainability.

\subsection{The Emergy concept and Emergy Accounting}

First introduced, as mentioned above, by Odum $(1988 ; 1996)$, and later systematised by - among others - Brown and Ulgiati (2016a; 2016b), the emergy concept allows to quantify, under the same unit, all the resource investments that are overall required to realise a product or a service - in our case, the vegetables produced within a CSA organic farming project in Italy. Emergy is defined as "the available energy of one kind previously used directly or indirectly to generate a service or a product". Through it, the performances of a given system can be assessed based on a common energy metrics: in most cases, the solar emjoule (sej), which is elaborated based on solar equivalent exergy and whose unit is the solar equivalent joule (seJ). The sum of the emergy requirements (energy, matter, labour, information, services) per unit of output is defined as Unit Emergy Value (UEV) and measured in sej/unit (sej/J, sej/kg, sej/h, sej/bit, sej/currency, etc.). Emergy per exergy unit is called transformity (sej/J), emergy per mass unit is defined as specific emergy (sej/kg). More than simply an environmental accounting method, the emergy accounting approach allows to keep track of both the natural cycles required to generate and concentrate resources over time and of the anthropic processes to extract, manufacture, and delivery such resources and/or more elaborated products and services. Emergy is sometimes considered as an evolution of the embodied energy concept (Costanza, 1980). Compared to an embodied energy analysis, an Emergy Assessment (EMA) shows a boundary expansion over space (since it accounts for large-scale phenomena that indirectly contribute to the local dynamics), over time (as it includes the processes required for resource generation and concentration), and over resource category (forasmuch as it also considers natural flows such as solar radiation, geothermal heat, wind, rain, and gravitational energy) (Cristiano \& Gonella, 2019). Furthermore, it might be worth noting that an EMA allows to also account for the resources required to provide important inputs such as labour and services (i.e. indirect labour). These virtually carry fractions of the material and immaterial requirements associated with the larger human economies in which the studied system is embedded (Ulgiati \& Brown, 2014). As noted e.g. in Cristiano et al. (forthcoming), this aspect "cannot be disregarded if a comprehensive sustainability evaluation is the goal", providing instead "an added value to the assessment, much beyond and certainly complementing the usual monetary and energy evaluations". An EMA starts with the definition of the boundaries of the process or system it studies, together with the drawing of the systems diagram, using the energy systems language (Odum, 1994). Building upon these, the driving flows (energy, matter, and so on) are identified and quantified, usually organised in categories: $(\mathrm{R})$ local renewable resources, provided for free; $(\mathrm{N})$, local nonrenewables from within the system; (F) other goods, imported from the outside; and (L\&S) labour and services. These inputs are then converted into emergy units by resorting to suitable UEVs, referred to the same global emergy baseline (GEB, i.e. the total renewable emergy driving the geobiosphere in one year). Here, the most recent $\mathrm{GEB}_{2016}$ of $1.20 \mathrm{E}+25 \mathrm{seJ} / \mathrm{yr}$ is adopted (Brown et al., 2016). Within an EMA, emergy indicators (Odum, 1996) can be selected and calculated; here: the emergy yield ratio (EYR), the emergy investment ratio (EIR), the environmental loading ratio (ELR), the emergy sustainability index (ESI), the renewable emergy percentage (\%Ren), and the areal empower intensity (AEI). These indicators are generally present in most EMAs; 
however, their significance is recalled below in the Discussion. An additional indicator is adopted in this study, i.e. the renewable support area $\left(\mathrm{SA}_{(\mathrm{r})}\right)$ : according to Brown and Ulgiati (2001), it represents the equivalent Earth surface that is required to support the investigated processes; it builds upon the local renewable empower density $\left(\operatorname{Empd}_{(\mathrm{r})}\right.$, calculated as the ratio between the annual $R$ flow and the area of the system).

\subsection{Previous Emergy evaluations of agricultural systems}

The EMA approach has been already used in multiple ecological evaluations involving agriculture. Nevertheless, this full study represents a complete novelty in its kind, in that it addresses for the first time a Community-Supported Agriculture project and, to the best of our knowledge, a non-market and bottom-up farming venture in general, seeking ecological sustainability and social equity altogether. As detailed below, this work is also one of the few ones addressing organic vegetable productions. At a country level, EMA has been so far applied to conduct evaluations of national agriculture in China (Chen et al., 2006; Tao et al., 2013; Liu et al., 2019), Denmark (Rydberg \& Haden, 2006), India and Pakistan (Ali et al., 2019), Korea (Lee et al., 2005); Japan (Gasparatos, 2011); Puerto Rico (González-Mejía \& Ma, 2017, Poland (LewandowskaCzarnecka et al., 2019), and the United States of America (Park et al., 2016). At a regional or provincial level, Lefroy and Rydberg (2003) focused on three crops in southwestern Australia; Wang et al. (2007) studied petroleum-based agriculture in the Shandong region, China; De Barros et al. (2009) evaluated the banana production in Guadalupe, Antilles; Agostinho et al. (2010) explored the agricultural economic sector of São Paulo state, Brazil, while Ghisellini et al. (2014) did the same for regions Campania and Emilia Romagna, Italy; three cropping systems in the Pampa Region, Argentina, were addressed by Ferraro and Benzi (2015); and $\mathrm{Su}$ et al. (2020) have recently assessed three types of agricultural production in Tongxiang, China. At a more local level, we can mention the Pakistani area of Bahawalnagar, in Punjab (Shah et al., 2019) and a series of Chinese districts: Manas county (Dong et al., 2011), Yanchi county (Wang et al., 2014), Gaomi city, in Shandong (Wang et al., 2019), and Chongming island (Zhan et al., 2019). Here, the interest is mostly for farming, while some authors address agriculture in combination with other kinds of food productions; among these, maize, pond fish, duck, and mushroom (Zhang et al., 2012), agro-livestock integration (Patrizi et al., 2018), and agrobusinesses involving crops, dairy products, and meat (Almeida et al., 2020). There is no interest for energy-oriented agricultural production either, as instead addressed e.g. by Jiang et al. (2007) and, recently, by Spagnolo et al. (2020). Among studies dealing with topics more similar to ours, crop-specific assessment were conducted on the production of: conventional corn in Kansas, USA, blackberry in Ohio, USA, and a Lacandon polycultural rotation system in Chiapas, Mexico (Martin et al., 2006); peach around Beijing, China (Wei et al., 2009); tropical fruit production at the estuary of the Pearl River in China (Lu et al., 2009); rice and vegetables in Chinese alluvial paddy fields ( $\mathrm{Lu}$ et al., 2010); three selected agricultural products, although focusing on their irrigation issues (Chen et al., 2014); maize in China (Zhai et al., 2018); wheat and maize in southwestern Iran (Houshyar et al., 2018); and bean in Iran (Asgharipour et al., 2019). Not many authors have so far addressed organic productions. Few medium- and large-scale organic cases can be found, dealing with: wine in Tuscany, Italy (Pizzigallo et al., 2008); wheat in Opolskie Voivodeship, Poland (Kuczuk, 2016); maize-wheat rotation in Uttarakhand, India (Singh et al., 2016); date and pistachio in eastern Iran (Jafari et al., 2018); and coffee (Giannetti et al., 2011) and soybean (Ortega et al., 2005), both in the Brazilian Cerrado. Out of proper EMA, but still involving the emergy concept while addressing organic productions, the production of all China was mentioned in Zhang et al. (2016), some reviews were conducted by Lynch et al. (2011) and Smith et al. (2015), while a theoretical comment was offered by Bastianoni et al. (2007). The publications assessing small organic products by means of EMA are even fewer: castorbean in Brazil (Comar et al., 2004); red orange in Italy (La Rosa et al., 2008); and horticultural products in the UK (Markussen et al., 2014) and Brazil (Nakajima \& Ortega, 2015). Small academically-led experiments on organic urban farming on backyard plots were evaluated through EMA in Columbus, Ohio, by Beck et al. (2001). The emergy potential to study the gainings and possible sustainability of small-scale organic project like urban gardening has been recently suggested by McDougall et al. (2019). However, to the best knowledge of the author, no local, small farms, short-supply chains, prosumer and/or community-led production processes have been ever studied before.

\subsection{The case study: horticultural co-production at CSA Veneto, Italy}

In this work, a horticultural co-production system is studied, inspired by the Community-Supported Agriculture (CSA) model (see the Introduction). In a highly industrialised area of Northern Italy, with significant wild land consumption, an alternative bottom-up experience is aimed at providing vegetables in a 
short and cooperative not-for-sale supply chain. Local organic farming and just labour conditions seek ecological sustainability and social equity beyond market dynamics: households and individuals gather to run a project that also aims at contributing to the resilience of its territory (furthermore currently affected by health and economic plights; see also Cristiano \& Gonella, 2020). The project is called CSA Veneto. In the next few lines, a detailed description is elaborated and integrated from Cristiano et al. (2021). The urban sprawl between Treviso and Venice has an old farming tradition, partly halted by an industrial development in the second half of the $20^{\text {th }}$ century. CSA Veneto started in early 2018, after a half-year trial period. It makes use of a historic organic farm in the area around Preganziol. Every year, its participants fund a share for getting food (including the farmers), sometimes co-owned by different individuals and/or households. Shares are around 40, thus involving more than 100 persons. Food provision planning overlaps with crop calendar planning. Production costs and decisions, just like risks and vegetal yield, are all shared. The crop calendar is proposed every year by an agro-technical working group, and approved by an assembly. The type and amount of the vegetables are decided based on the community needs and preferences and on soil and climate conditions. An organisational plan is also designed to estimate, discuss, and decide e.g. on production costs, the farmers' salaries, the operating costs for distribution, and, finally, the total monetary budget is completed. During an assembly, the total amount is divided by the number of desired shares (from individuals and households) so as to calculate an average share price to support the venture for the following year. Based upon such average price, anyone can anonymously propose the amount they wish to (and are capable of) offering. This way, mutual aid, social inclusion, and partial redistribution of monetary wealth is performed. If the total amount needed is not reached during a first round of secret proposals, rounds are repeated until fulfilment. After this, the production and (later) the distribution phases can begin. Following agricultural progresses, every week the produce is driven to five distribution points: Preganziol (4 km), and Mogliano Veneto $(7 \mathrm{~km})$, Treviso $(15 \mathrm{~km})$, Mestre $(15 \mathrm{~km})$, and old town Venice $(27 \mathrm{~km})$. There, the share-holding members find no pre-packaged crates, but rather pick up their food according to fair "dividends" of the weekly vegetables. On average, each share contains $5 \mathrm{~kg}$ of horticultural products every week: with 40 shares and 50 annual weeks, CSA Veneto produces 10 ton of vegetables annually. Each member spends some time to collect their share, but this tend to be no more than what is needed when grocery shopping, so this time is not considered in this EMA ${ }^{1}$. Some help out with minor CSA tasks (supporting farming, distribution, communication, outreach, and accounting), some are active in open and horizontal budget committes, agro-technical committees, and quarterly administrative meetings, while most participate in the annual assembly. Their time, i.e. voluntary work, is computed in this assessment. In addition to the information reported above, the raw data for the present EMA are taken, inferred, and/or elaborated from CSA Veneto's annual budget and production spreadsheets, and integrated via several field visits and interviews. Key data is summarised in Table 1, crop details are reported in Table 2, and all raw data for the EMA at hand is anyway contained in Table 3 and in its footnotes.

Table 1. CSA Veneto's key data in brief, year 2018

\begin{tabular}{|l|c|}
\hline Farming area & $0.45 \mathrm{ha}=4,500 \mathrm{~m}^{2}$ \\
\hline Horticular production & 10 ton $=10,000 \mathrm{~kg}$ \\
\hline Community shares & 40 \\
\hline Distribution weeks & 50 \\
\hline Equivalent full-time workers, paid & 1 \\
\hline Equivalent full-time workers, voluntary & 0.1 \\
\hline Budget & $24,500 €$ \\
\hline
\end{tabular}

Table 2. CSA Veneto horticultural production, year 2018

\begin{tabular}{|l|c|}
\hline Aubergine, or eggplant (Solanum melongena) & $420 \mathrm{~kg}$ \\
\hline Beet (Beta vulgaris) & $200 \mathrm{~kg}$ \\
\hline Cabbage (Brassica oleracea var. capitata) & $920 \mathrm{~kg}$ \\
\hline Celery (Apium graveolens) & $20 \mathrm{~kg}$ \\
\hline Chard (Beta vulgaris var. cicla) & $1,280 \mathrm{~kg}$ \\
\hline Chicory (Cichorium intybus) & $960 \mathrm{~kg}$ \\
\hline Cima di rapa [IT] (Brassica rapa sylvestris var. esculenta) & $100 \mathrm{~kg}$ \\
\hline Common bean, or French bean (Phaseolus vulgaris) & $200 \mathrm{~kg}$ \\
\hline Corn salad, or mâche (Valerianella locusta) & $180 \mathrm{~kg}$ \\
\hline
\end{tabular}

\footnotetext{
${ }^{1}$ The time spent for enjoying a service can be accounted as a type of labour, as e.g. in Cristiano \& Gonella (2019).
} 


\begin{tabular}{|l|c|}
\hline Courgette, or zucchini (Cucurbita pepo) & $400 \mathrm{~kg}$ \\
\hline Cucumber (Cucumis sativus) & $300 \mathrm{~kg}$ \\
\hline Fennel (Foeniculum vulgare) & $1,000 \mathrm{~kg}$ \\
\hline Green bean (Pisum sativum) & $200 \mathrm{~kg}$ \\
\hline Leek (Allium ampeloprasum) & $280 \mathrm{~kg}$ \\
\hline Lettuce (Lactuca sativa) & $500 \mathrm{~kg}$ \\
\hline Muskmelon (Cucumis melo) & $240 \mathrm{~kg}$ \\
\hline Onion (Allium cepa) & $200 \mathrm{~kg}$ \\
\hline Parsley (Petroselinum crispum) & $28 \mathrm{~kg}$ \\
\hline Pepper, or bell pepper (Capsicum annuum) & $420 \mathrm{~kg}$ \\
\hline Potato (Solanum tuberosum) & $200 \mathrm{~kg}$ \\
\hline Pumpkin (Cucurbita maxima and Cucurbita moschata) & $400 \mathrm{~kg}$ \\
\hline Radicchio Rosso di Treviso [IT] (variety of Cichorium intybus) & $336 \mathrm{~kg}$ \\
\hline Radish (Raphanus sativus) & $120 \mathrm{~kg}$ \\
\hline Rocket, or arugula (Eruca vesicaria) & $96 \mathrm{~kg}$ \\
\hline Spinach (Spinacia oleracea) & $320 \mathrm{~kg}$ \\
\hline Tomato (Solanum lycopersicum) & $360 \mathrm{~kg}$ \\
\hline Watermelon (Citrullus lanatus) & $320 \mathrm{~kg}$ \\
\hline
\end{tabular}

\section{Results}

\subsection{Diagram for organic food production in a community-supported agriculture (CSA) system}

The systems diagram for our case study is presented in Figure 1. The driving flows are visualised (and then quantified, see Section 3.2) in terms of energy, materials, goods, labour, and services. Physically, the boundary of the CSA Veneto overlaps with the portion of the farm dedicated to the project. The temporal boundary is one year. This is the timeframe in which members of the community can enter or leave the group, and to which both crop planning and budget planning are referred. At the beginning of the study, 2018 was the most recent year with full and validated data. Updates for the following years can be easily made thanks to well organised internal reports and to tailored choices made during this accounting.

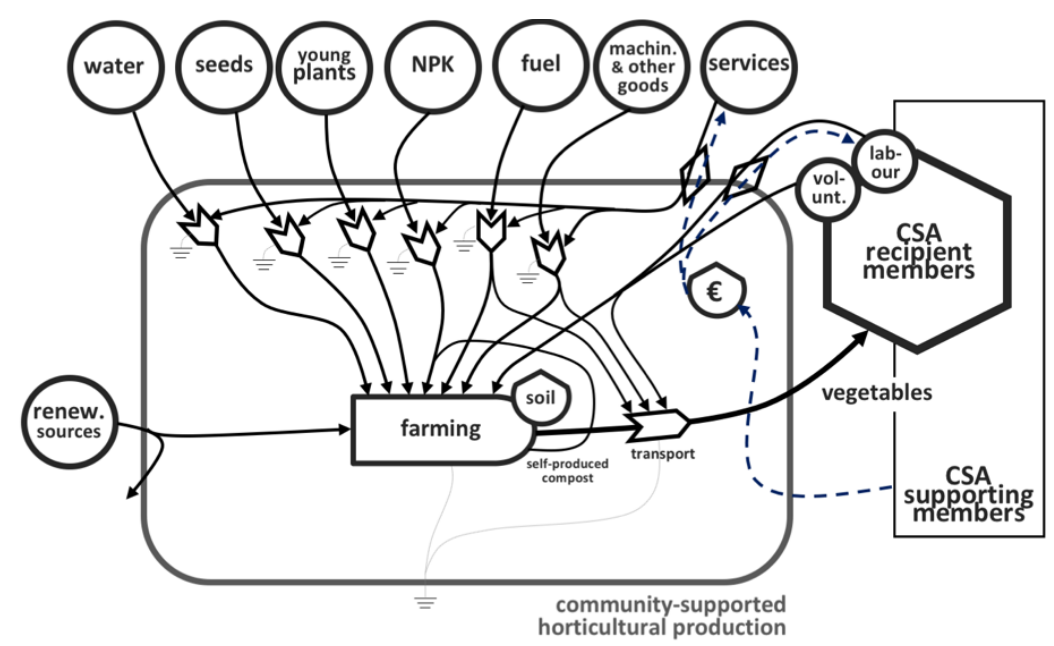

Figure 1. Systems diagram for food production in a community-supported agriculture project

\subsubsection{Diagram for organic food production}

The main process if course represented by farming (framed in a bullet symbol since based on photosynthesis). Farming is contributed by and contributes to local soil, expressed as a stock connected to the process. Farming also profits from renewable sources, although it does not exploit them all. CSA Veneto takes irrigation water from human-made irrigation channels, close to its fields but still out of the system (and of its control). Organic seeds and young plants to be grown are purchased from a certified supplier. Crucial nutrients for agriculture such as nitrogen $(\mathrm{N})$, phosphorous $(\mathrm{P})$, and potassium $(\mathrm{K})$ are also imported. Unlike conventional farming, no 
synthetic fertilisers are used. Some compost is self-produced by both growing green manure and reusing horticultural by-products (non-edible leaves, damaged fruits, etc.). Tools, infrastructures, and structures all fit into the "machinery and other goods" source in the diagram, i.e. are imported into the system from the external economies, together with vehicles and farming machines, in turn requiring another input: fuel. As per systems diagramming praxis, all imported inputs are associated with services, i.e. indirect labour that was previously needed (outside the system) to manufacture the products, to delivery it, and/or to make the related structers and infrastructures required for all of that. Services also represent external (indirect) labour of which the system might avail itself: this might result in consultancy, training, maintenance, and occasional farming operations. Services are usually exchanged for money (dashed flows). A van and some fuel are also required to transfer the produce to the urban and peri-urban distribution points.

\subsubsection{Peculiarities of the diagram of a community-supported agriculture system}

The most distinctive features of a non-market, cooperative, and mutualist agricultural project lie in the right side of the diagram. The horticultural produce is not sold, so the recipients (in a hexagonal consumer stock) receive vegetables independent of whether and how much money are contributed to the project; indeed, the latter is funded by supporting members not necessarily overlapping with the recipients: shares can be secretely donated or at least partly waived. Also, paid workers are part of the community, and volunteering is offered for manual and management tasks: although unpaid work, this is needed and is therefore kept track of.

\subsection{Emergy flows of horticultural production at CSA Veneto}

The first quantitative part of the EMA starts with the inventory and its emergy conversion as illustrated in Table 3. The flows are organised in groups: local renewable inputs $(\mathrm{R})$, local nonrenewable sources $(\mathrm{N})$, purchased material inputs from the outer economies (F), and labour and services (L\&S). When required, i.e. for stocks and flows having a longer lifetime, raw data is only referred to one year; all the information about these as well as other details about raw data is reported in the footnotes. The adopted UEVs are appropriately chosen from solid existing literature, as referenced, and all converted to the $\mathrm{GEB}_{2016}$. In the light of the different specific energy contained in each plant species, the specific transformities for the several crops grown at CSA Veneto are separately illustrated in Table 4.

Table 3. Emergy accounting of the annual organic vegetable production at CSA Veneto, Italy, 2018

\begin{tabular}{|c|c|c|c|c|c|c|}
\hline \# & Item & Unit & $\begin{array}{l}\text { Annual } \\
\text { amount }\end{array}$ & $\begin{array}{c}\text { UEV } \\
\text { (sej/unit) }\end{array}$ & $\begin{array}{l}\text { UEV } \\
\text { ref. }\end{array}$ & $\begin{array}{l}\text { Solar emergy } \\
(\mathrm{E}+12 \mathrm{sej} / \mathrm{yr})\end{array}$ \\
\hline \multicolumn{7}{|c|}{ Local renewable inputs $(R)$} \\
\hline 1 & Solar radiation & $\mathrm{J}$ & $2.29 \mathrm{E}+13$ & 1 & [a] & 17 \\
\hline 2 & Geothermal heat flow & $\mathrm{J}$ & $5.67 \mathrm{E}+09$ & 4,900 & [b] & 35 \\
\hline 3 & Wind, kinetic energy & $\mathrm{J}$ & $1.77 \mathrm{E}+09$ & 790 & {$[\mathrm{~b}]$} & 1 \\
\hline \multirow[t]{2}{*}{4} & Rain, geopotential & $\mathrm{J}$ & $4.84 \mathrm{E}+08$ & 12,800 & [b] & 3 \\
\hline & & & \multicolumn{3}{|c|}{ Driving renewable input ${ }^{* *}$} & 52 \\
\hline \multicolumn{7}{|c|}{ Local nonrenewable sources $(\mathrm{N})$} \\
\hline 5 & Topsoil & $\mathrm{J}$ & $3.51 \mathrm{E}+09$ & $9.37 \mathrm{E}+04$ & {$[\mathrm{c}]$} & 329 \\
\hline \multicolumn{7}{|c|}{ Imported material inputs (F) } \\
\hline 6 & Seeds, for vegetables & $\mathrm{kg}$ & 20 & $2.30 \mathrm{E}+12$ & {$[\mathrm{~d}]$} & 46 \\
\hline 7 & Seeds, for green manure (self-produced compost) & $\mathrm{kg}$ & 2 & $2.30 \mathrm{E}+12$ & [d] & 5 \\
\hline 8 & Seedlings (young plants) & item & 820 & $7.58 \mathrm{E}+12$ & {$[\mathrm{e}]$} & 6,222 \\
\hline 9 & Organic manure (NPK) & $\mathrm{kg}$ & 1,805 & $6.41 \mathrm{E}+12$ & [f] & 11,570 \\
\hline 10 & Organic plant protection products & $\mathrm{kg}$ & 3.3 & $3.89 \mathrm{E}+12$ & [g] & 13 \\
\hline 11 & Water, for irrigation (from stream) & $\mathrm{m}^{3}$ & 4,500 & $1.00 \mathrm{E}+11$ & [b] & 450 \\
\hline 12 & Hardware, steel & $\mathrm{kg}$ & 0.3 & $3.26 \mathrm{E}+12$ & [h] & 1 \\
\hline 13 & Irrigation system, plastics & $\mathrm{kg}$ & 45 & $6.48 \mathrm{E}+12$ & [h] & 292 \\
\hline 14 & Greenhouse, steel parts & $\mathrm{kg}$ & 6 & $3.26 \mathrm{E}+12$ & {$[\mathrm{~h}]$} & 20 \\
\hline 15 & Greenhouse, plastic parts & $\mathrm{kg}$ & 30 & $6.48 \mathrm{E}+12$ & [h] & 194 \\
\hline 16 & Electricity & $\mathrm{J}$ & $2.77 \mathrm{E}+09$ & $2.20 \mathrm{E}+05$ & [i] & 610 \\
\hline 17 & Farming machines & $\mathrm{kg}$ & 750 & $6.87 \mathrm{E}+12$ & [j] & 5,153 \\
\hline 18 & Vehicle for deliveries (van) & $\mathrm{kg}$ & 150 & $6.87 \mathrm{E}+12$ & [j] & 1,031 \\
\hline 19 & Fuel, for deliveries & $\mathrm{kg}$ & 668 & $6.40 \mathrm{E}+12$ & [k] & 4,276 \\
\hline 20 & Fuel, for purchases & $\mathrm{kg}$ & 89 & $6.40 \mathrm{E}+12$ & {$[\mathrm{k}]$} & 570 \\
\hline 21 & Fuel, for farming machines & $\mathrm{kg}$ & 111 & $6.40 \mathrm{E}+12$ & {$[\mathrm{k}]$} & 713 \\
\hline
\end{tabular}


Labour and services (L\&S)

22 Labour, theoretical equivalent full time salary

23 Volunteers, equivalent full time workers

24 Contractors, external farming operations

25 Contractors, external maintenance

26 Contractors, workers' training and retraining

27 Fields rent

28 Seed purchase, for vegetables

29 Seed purchase, for green manure

30 Seedling purchase

31 Organic fertiliser purchase

32 Protection product + hardware purchase

33 Greenhouse and irrigation system

34 Electricity

35 Farming machine purchase

36 Insurance

37 Fuel

38 Organic certification

\begin{tabular}{|c|c|c|c|c|}
\hline$€$ & 18,760 & $1.90 \mathrm{E}+12$ & [i] & 38,614 \\
\hline item & 0.1 & $7.96 \mathrm{E}+16$ & [i] & 7,960 \\
\hline$€$ & 440 & $1.90 \mathrm{E}+12$ & [i] & 836 \\
\hline$€$ & 280 & $1.90 \mathrm{E}+12$ & [i] & 532 \\
\hline$€$ & 100 & $1.90 \mathrm{E}+12$ & [i] & 190 \\
\hline$€$ & 1,800 & $1.90 \mathrm{E}+12$ & [i] & 3,420 \\
\hline$€$ & 100 & $1.90 \mathrm{E}+12$ & [i] & 190 \\
\hline$€$ & 40 & $1.90 \mathrm{E}+12$ & [i] & 190 \\
\hline$€$ & 2,051 & $1.90 \mathrm{E}+12$ & [i] & 3,897 \\
\hline$€$ & 2,383 & $1.90 \mathrm{E}+12$ & [i] & 4,528 \\
\hline$€$ & 100 & $1.90 \mathrm{E}+12$ & [i] & 190 \\
\hline$€$ & 1,000 & $1.90 \mathrm{E}+12$ & [i] & 1,900 \\
\hline$€$ & 308 & $1.90 \mathrm{E}+12$ & [i] & 585 \\
\hline$€$ & 1,250 & $1.90 \mathrm{E}+12$ & [i] & 2,375 \\
\hline$€$ & 390 & $1.90 \mathrm{E}+12$ & [i] & 741 \\
\hline$€$ & 1,560 & $1.90 \mathrm{E}+12$ & [i] & 2,964 \\
\hline \multirow[t]{11}{*}{$€$} & 625 & $1.90 \mathrm{E}+12$ & [i] & 1,188 \\
\hline & & sej/yr & no L\&S & $3.15 E+16$ \\
\hline & & $\mathrm{sej} / \mathrm{yr}$ & with L\&S & $1.02 E+17$ \\
\hline & & $\mathrm{kg} / \mathrm{yr}$ & & 10,000 \\
\hline & & item & & 40 \\
\hline & & $€ / y r$ & & 600 \\
\hline & & sej/kg & no L\&S & $3.15 E+12$ \\
\hline & & $\mathrm{sej} / \mathrm{kg}$ & with L\&S & $1.02 \mathrm{E}+13$ \\
\hline & & sej/item & no L\&S & $7.89 \mathrm{E}+14$ \\
\hline & & sej/item & no L\&S & $2.55 E+15$ \\
\hline & & sej/€ & with L\&S & $1.70 \mathrm{E}+14$ \\
\hline
\end{tabular}

Total emergy input (U)

Total emergy input (ULS)

Organic vegetable produce

Number of shares (households) in the project

Average monetary contribution per share

Specific emergy of organic vegetable produce

\section{Annual emergy per share (household)}

\section{Emergy per average contributed money unit}

${ }^{*}$ Calculated or converted from other works according to the $\mathbf{G E B}_{2016} \mathbf{0 f} \mathbf{1 . 2 E}+\mathbf{2 5}$ sej (Brown et al., 2016)

**As per Brown \& Ulgiati (2016b), we use the largest between the sum of the tripartite sources (solar radiation, heat flow, and tides, where applicable) and the largest of secondary and tertiary sources (here, wind and rain).

Footnotes: Area of the production fields: 4,500 $\mathrm{m}^{2} .1$. Annual solar insolation in the Venice-Treviso area, Italy, year $2018: 5,094 \mathrm{MJ} / \mathrm{m}^{2}($ after ARPAV, 2020); albedo of greenery: 0.26 (UNI, 1983). 2. Local heat flow: $50 \mathrm{~mW} / \mathrm{m}^{2}$ (after Della Vedova et al., 2001). 3. Average annual local surface wind speed, year 2018 (closest station: Mogliano Veneto, $<10 \mathrm{~km}$ ): $1.3 \mathrm{~m} / \mathrm{s}$ (ARPAV, 2020); surface wind / geostrophic wind ratio: 0.6 (our assumption based on previous literature); drag coefficient: 1.00E-03 (Miller, 1964); average density of air in the area: $1.225 \mathrm{~kg} / \mathrm{m}^{3}$ (our calculation based on local elevation). 4. Elevation: $12 \mathrm{~m}$ (Preganziol official records); annual rainfall, year 2018: $915.2 \mathrm{~mm}$ (ARPAV, 2020); runoff: 0.5 (our estimation based on previous literature). 5. Erosion rate estimated at $0.69 \mathrm{~kg} / \mathrm{m}^{2} / \mathrm{yr}$ (La Rosa et al., 2008); average carbon concentration in topsoil: 5\% (after De Vilbiss and Brown, 2015); energy content in soil 5,400 kcal/kg (Ulgiati et al., 1992). 6-10. Raw data extracted and/or elaborated based on CSA Veneto annual sheets and interviews with their authors. 11. Since water is taken from irrigation channels (see our Section 3.1.1), no record is available at CSA Veneto, so data come from the most recent official census on agriculture by latitude and crop types (ISTAT, 2012). 12-15. Our calculations based on CSA Veneto annual sheets and interviews with their authors; assumed lifetime is 10 years, except for greenhouse steel parts (20 years). 16. Based on annual expenditure and average electricity price in $2018(0.4 € / \mathrm{kWh}$, including taxes and fixed costs). 17-18. Our calculations based on CSA Veneto annual sheets and interviews with their authors; assumed lifetime is 20 years. 19-21. Based on annual expenditure, average price for diesel in $2018(\sim 1.53 € / \mathrm{L})$, and diesel density $(0.85 \mathrm{~kg} / \mathrm{L})$. 22. Two junior farmers and one farmer work $33.3 \%$ part-time with self-reduced salaries to support this project; here, their labour is accounted as a weighted average national average gross salary for junior $(19,337 €)$ and senior $(22,295 €)$ farmers, based data from Italian social security agency for farmers CIMAAV (2019), year 2018. 23-38. Based on CSA Veneto annual sheets; stocks lasting longer than one year follow an amortisation based on the same lifetime expressed above. UEV references: a. By definition. b. After De Vilbiss \& Brown (2015). c. Odum (1996). d. Fahd et al. (2012). e. Markussen et al. (2014). f. Weighted NPK mix, calculated after Spagnolo et al. (2020). g. Campbell et al. (2005a). h. Brown \& Buranakarn (2003). i. National Environmental Accounting Database, Italy, 2014 (after Sweeney et al., 2007). j. Lou et al. (2015). k. Brown et al. (2011).

Table 4. New transformities, community-supported organic horticultural production

\begin{tabular}{|c|c|c|c|}
\hline \multirow[t]{2}{*}{$\begin{array}{c}\text { Crop } \\
\text { (Specific emergy for all, from this work: } \\
\text { 3.15E+12 sej/kg without L\&S, } \mathbf{1 . 0 2 E}+\mathbf{1 3} \text { sej/kg with } L \& S)\end{array}$} & \multirow[t]{2}{*}{$\begin{array}{l}\text { Specific } \\
\text { energy } \\
(\mathrm{J} / \mathrm{kg})^{* * *}\end{array}$} & \multicolumn{2}{|c|}{$\begin{array}{l}\text { Transformity } \\
\qquad(\mathrm{sej} / \mathrm{J}) \\
\text { (source: this work) }\end{array}$} \\
\hline & & without $L \& S$ & with $L \& S$ \\
\hline Aubergine, or eggplant (Solanum melongena) & $1.05 \mathrm{E}+06$ & $3.00 \mathrm{E}+06$ & $9.71 \mathrm{E}+06$ \\
\hline Beet (Beta vulgaris) & $9.20 \mathrm{E}+05$ & $3.42 \mathrm{E}+06$ & $1.11 \mathrm{E}+07$ \\
\hline Cabbage (Brassica oleracea var. capitata) & $1.05 \mathrm{E}+06$ & $3.00 \mathrm{E}+06$ & $9.71 \mathrm{E}+06$ \\
\hline Celery (Apium graveolens) & $5.86 \mathrm{E}+05$ & $5.38 \mathrm{E}+06$ & $1.74 \mathrm{E}+07$ \\
\hline Chard (Beta vulgaris var. cicla) & $7.95 \mathrm{E}+05$ & $3.96 \mathrm{E}+06$ & $1.28 \mathrm{E}+07$ \\
\hline Chicory (Cichorium intybus) & $1.34 \mathrm{E}+06$ & $2.35 \mathrm{E}+06$ & $7.61 \mathrm{E}+06$ \\
\hline Cima di rapa [IT] (Brassica rapa sylvestris var. esculenta) & $7.53 \mathrm{E}+05$ & $4.18 \mathrm{E}+06$ & $1.35 \mathrm{E}+07$ \\
\hline Common bean, or French bean (Phaseolus vulgaris) & $7.87 \mathrm{E}+06$ & $4.00 \mathrm{E}+05$ & $1.30 \mathrm{E}+06$ \\
\hline
\end{tabular}




\begin{tabular}{|l|l|l|l|}
\hline Corn salad, or mâche (Valerianella locusta) & $6.28 \mathrm{E}+05$ & $5.02 \mathrm{E}+06$ & $1.62 \mathrm{E}+07$ \\
\hline Courgette, or zucchini (Cucurbita pepo) & $7.53 \mathrm{E}+05$ & $4.18 \mathrm{E}+06$ & $1.35 \mathrm{E}+07$ \\
\hline Cucumber (Cucumis sativus) & $6.28 \mathrm{E}+05$ & $5.02 \mathrm{E}+06$ & $1.62 \mathrm{E}+07$ \\
\hline Fennel (Foeniculum vulgare) & $1.30 \mathrm{E}+06$ & $2.42 \mathrm{E}+06$ & $7.85 \mathrm{E}+06$ \\
\hline Green bean (Pisum sativum) & $1.30 \mathrm{E}+06$ & $2.42 \mathrm{E}+06$ & $7.85 \mathrm{E}+06$ \\
\hline Leek (Allium ampeloprasum) & $2.55 \mathrm{E}+06$ & $1.24 \mathrm{E}+06$ & $4.00 \mathrm{E}+06$ \\
\hline Lettuce (Lactuca sativa) & $5.86 \mathrm{E}+05$ & $5.38 \mathrm{E}+06$ & $1.74 \mathrm{E}+07$ \\
\hline Muskmelon (Cucumis melo) & $1.42 \mathrm{E}+06$ & $2.22 \mathrm{E}+06$ & $7.18 \mathrm{E}+06$ \\
\hline Onion (Allium cepa) & $1.67 \mathrm{E}+06$ & $1.89 \mathrm{E}+06$ & $6.11 \mathrm{E}+06$ \\
\hline Parsley (Petroselinum crispum) & $5.86 \mathrm{E}+05$ & $5.38 \mathrm{E}+06$ & $1.74 \mathrm{E}+07$ \\
\hline Pepper, or bell pepper (Capsicum annuum) & $9.20 \mathrm{E}+05$ & $3.42 \mathrm{E}+06$ & $1.11 \mathrm{E}+07$ \\
\hline Potato (Solanum tuberosum) & $6.35 \mathrm{E}+07$ & $4.96 \mathrm{E}+04$ & $1.61 \mathrm{E}+05$ \\
\hline Pumpkin (Cucurbita maxima and Cucurbita moschata) & $1.09 \mathrm{E}+06$ & $2.89 \mathrm{E}+06$ & $9.36 \mathrm{E}+06$ \\
\hline Radicchio Rosso di Treviso $[\mathrm{IT}]$ (variety of Cichorium intybus) & $1.34 \mathrm{E}+06$ & $2.35 \mathrm{E}+06$ & $7.61 \mathrm{E}+06$ \\
\hline Radish (Raphanus sativus) & $6.69 \mathrm{E}+05$ & $4.71 \mathrm{E}+06$ & $1.52 \mathrm{E}+07$ \\
\hline Rocket, or arugula (Eruca vesicaria) & $1.05 \mathrm{E}+06$ & $3.00 \mathrm{E}+06$ & $9.71 \mathrm{E}+06$ \\
\hline Spinach (Spinacia oleracea) & $9.62 \mathrm{E}+05$ & $3.27 \mathrm{E}+06$ & $1.06 \mathrm{E}+07$ \\
\hline Tomato (Solanum lycopersicum) & $7.53 \mathrm{E}+05$ & $4.18 \mathrm{E}+06$ & $1.35 \mathrm{E}+07$ \\
\hline Watermelon (Citrullus lanatus) & $1.26 \mathrm{E}+06$ & $2.50 \mathrm{E}+06$ & $8.10 \mathrm{E}+06$ \\
\hline
\end{tabular}

V*** Values from USDA (2019), except for potato, coming from FAO (2003), Chapter 3, based on the method by Merrill \& Watt (1973). 3.3. Emergy sustainability indicators and novel UEVs (transformity and specific emergy)

All emergy values are expressed both with and without labour and services. Specific emergy is the same for all the organic vegetables produced within the CSA Veneto project in 2018 (see Tables 3 and 4), i.e. $3.15 \mathrm{E}+12 \mathrm{sej} / \mathrm{kg}$ without labour and services and $1.02 \mathrm{E}+13 \mathrm{sej} / \mathrm{kg}$ with labor and services. Instead, the newly found transformities vary from crop to crop, as expressed in Table 4, depending on their specific energy. The produced mass values for each crop are illustrated in Table 2 . Transformities are particularly important since we are dealing with food: this allows to ease the comparison with other products with different nutritional features. The specific emergy, instead, is particularly suitable for comparisons with the same crops produced elsewhere and/or other food products with similar specific energy content. Finally, some emergy sustainability indicators are calculated (as per Section 2.2) and presented in Table 5.

Table 5. Emergy sustainability indicators

\begin{tabular}{|c|c|c|}
\hline Category & Equation & Value (sej/yr) \\
\hline $\mathrm{R}$ & & $5.17 \mathrm{E}+13$ \\
\hline $\mathrm{N}$ & & $3.29 \mathrm{E}+14$ \\
\hline $\mathrm{F}$ & & $3.12 \mathrm{E}+16$ \\
\hline L\&S & & $7.03 \mathrm{E}+16$ \\
\hline U & $\mathrm{R}+\mathrm{N}+\mathrm{F}$ & $3.15 \mathrm{E}+16$ \\
\hline ULS & $\mathrm{U}+\mathrm{L} \& \mathrm{~S}$ & $1.02 \mathrm{E}+17$ \\
\hline Indicator & Equation & Value \\
\hline EYR & $\mathrm{U} / \mathrm{F}$ & 1.012 \\
\hline $\mathrm{EYR}_{\mathrm{L \& S}}$ & $\mathrm{ULS} /(\mathrm{F}+\mathrm{L} \& \mathrm{~S})$ & 1.004 \\
\hline EIR & $\mathrm{F} /(\mathrm{R}+\mathrm{N})$ & 82 \\
\hline $\mathrm{EIR}_{\mathrm{L} \& \mathrm{~S}}$ & $(\mathrm{~F}+\mathrm{L} \& \mathrm{~S}) /(\mathrm{R}+\mathrm{N})$ & 267 \\
\hline ELR & $(\mathrm{F}+\mathrm{N}) / \mathrm{R}$ & 609 \\
\hline$E_{L L R}$ & $(\mathrm{~F}+\mathrm{N}+\mathrm{L} \& \mathrm{~S}) / \mathrm{R}$ & 1,969 \\
\hline$\% \mathrm{R}$ & $\mathrm{R} / \mathrm{U}$ & $0.16 \%$ \\
\hline$\% \mathrm{R}_{\mathrm{L} \& \mathrm{~S}}$ & $\mathrm{R} / \mathrm{ULS}$ & $0.05 \%$ \\
\hline ESI & EYR/ELR & 0.0017 \\
\hline $\mathrm{ESI}_{\mathrm{L} \& \mathrm{~S}}$ & $\mathrm{EYR}_{\mathrm{L \& S}} / \mathrm{ELR}_{\mathrm{L \& S}}$ & 0.0005 \\
\hline AEI & $\mathrm{U} /($ area $)$ & $7.0 \mathrm{E}+12 \mathrm{sej} / \mathrm{m}^{2}$ \\
\hline $\mathrm{AEI}_{\mathrm{L} \& \mathrm{~S}}$ & ULS/(area) & $2.3 \mathrm{E}+13 \mathrm{sej} / \mathrm{m}^{2}$ \\
\hline $\operatorname{Empd}_{(\mathrm{r})}$ & $\mathrm{R} /($ area $)$ & $1.2 \mathrm{E}+10 \mathrm{sej} / \mathrm{m}^{2}$ \\
\hline $\mathrm{SA}_{(\mathrm{r})}$ & $(\mathrm{F}+\mathrm{N}) / \mathrm{Empd}_{(\mathrm{r})}$ & 274 ha \\
\hline
\end{tabular}




$$
\mathrm{SA}_{(\mathrm{r}) \mathrm{L} \& \mathrm{~S}} \quad(\mathrm{~F}+\mathrm{N}+\mathrm{L} \& \mathrm{~S}) / \operatorname{Empd}_{(\mathrm{r})} \quad 886 \text { ha }
$$

\section{Discussion}

\subsection{A unique systems diagram}

The systems diagram of CSA Veneto shows unique features, mostly linked to its representing a nonmarket, cooperative, and mutualist agricultural project. Unlike most human economic processes, the output (here, the horticultural produce) is not sold, i.e. not given in exchange for monetary flows. This way, as introduced in Section 3.1.2, the recipients receive vegetables regardless of their financial contribution to the project; every year, indeed, the agricultural venture is funded by supporting members who do not necessarily overlap with the recipients thanks to secret donations and/or partial waivers. Another interesting peculiarity can be found in the human labour flows into the system, which are not all paid in the light of voluntary work (as seen already in Cristiano et al., 2018; Gonella et al., 2019; and Cristiano et al., forthcoming): this way, it is the input that is not exchanged for money. Still, both the output horticultural produce and the volunteering input require emergy that is here accounted for (as illustrated in the next sections). Finally, paid labour is offered from within the members of the cooperative project, which represents a novel feature, and can be seen as some progress toward local loops and social economies for and by the recipients exhibiting some demand. 4.2. On the driving emergy flows

Table 3 shows that the main energy and material inputs in the community-supported organic vegetable production at hand are represented by the organic manure (NPK) (37\%) and the certified seedlings (20\%), i.e. the little plants already grown in an organic nursery before transplantation into the fields of CSA Veneto. Other major inputs are the annual amortisation of the farming machines $(16 \%)$ and the fuel used to run the van for the deliveries (14\%). All the remaining inputs halt around 3\% or even much less. When labour and services are included, the farming work accounts for $38 \%$ of the total emergy requirements, followed by the voluntary work $(8 \%)$; the organic manure is now $11 \%$, and its associated services $4 \%$; the seedlings are resized to $6 \%$, and the services matched with their purchase add almost $4 \%$; the farming machines account for $5 \%$ (and their services $2 \%$ ); the fuel for the deliveries, for $4 \%$ (total fuels: $5 \%$, their services: $<3 \%$ ). In a conventional energyintensive agrobusiness production ( 89 ha, corn, USA), fertilisation and irrigation account for $95 \%$ of the total emergy inputs, with labour only representing $0.3 \%$ (Martin et al., 2006). For a quite undemanding crop in a small family plantation in a wet climate ( 1 ha, organic castorbean, Brazil), labour accounts for $6 \%$, fertilisation and irrigation for $84 \%$, yet coming from non-industrial inputs such as limestone (44\%), rain (31\%), and organic manure (9\%) (Comar et al., 2004). In a case study, closer to ours in terms of macroclimate, latitute, and size (1.8 ha, organic orange, Italy), the vegetable production requires $43 \%$ of labour and $10 \%$ of irrigation water and organic manure (La Rosa et al., 2008). Three case studies yielding similar horticultural products (averagely 6 ha, various organic vegetables, United Kingdom) have labour and service inputs higher than $90 \%$, water and nutrient inputs equal or smaller than $3 \%$ of the total emergy requirements, and certified seeds and seedlings reaching $23 \%$ of the energy and material inputs (Markussen et al., 2014). The previously published results exhibit extremely different values and significances, mainly based on the crop species, local geography and climate, conventional or organic farming, production scale, and so on. However, the values for CSA Veneto meet the same orders of magnitude for the leading inputs shared with similar productions:

- irrigation and fertilisation inputs: $12 \%$ (compared to $10 \%$ from La Rosa et al., 2008, both with L\&S); - certified seeds and seedlings: 20\% (compared to 23\% from Markussen et al., 2014, all excluding L\&S); - labour: 46\% (43\% in La Rosa et al., 2008), with services: 69\% (90\% in Markussen et al., 2014).

Although - as just seen - not representing an absolute exception, such percentages for labour and services are certainly a rarity in emergy accounting. This has already happened in systems displaying hi-tech and transgenic innovations (Rótolo et al., 2015a; 2015b) and skilled labour and patented pharmauceticals and instruments (Cristiano et al., forthcoming). As to the small and organic community-supported agricultural system at hand, instead, like the above cited Iorganic red orange in Italy and horticultural products in the United Kingdom, we are in the presence of labour-intensive farming processes, shifting to labour and services many of the their requirements from the energy and material inputs that are rather typical of energy-intensive agriculture. 


\subsubsection{A methodological remark about volunteering and labour accounting}

How to compute human contributions is still part of an active debate in emergy accounting (Abel, 2010; Campbell \& Lu, 2014; Kamp et al., 2016; Lupinacci \& Bonilla, 2018; Ulgiati \& Brown, 2012). Three main approaches can be identified: (a) relating it to the emergy per capita in a country, regardless of the type of labour and of the education required; (b) calculating labour based on the money through which it is exchanged (just like service) since salary would implicitly consider different responsibility levels, skills, and upstream societal efforts in education; and (c) integrating (a) with special calculations about the emergy associated with different educational degrees, anyway split over 40 year careers (this was calculated for the USA by Campbell $\& \mathrm{Lu}, 2014$, but is hardly applicable to all jobs and/or to other countries). In the present study, an option was therefore present between (a) and (b). In the spirit of the CSA Veneto project, the farmers have sober lifestyles, inspired by ecological sustainability: they "live with less", and their ecological footprints (Wackernagel \& Rees, 1996; Kitzes et al., 2007) are actually around 50\% of the average Italian value (Global Footprint Network, 2020). The Italian emergy per capita $(7.96 \mathrm{E}+16 \mathrm{sej} / \mathrm{yr})$ is adopted to account for the volunteering, based on equivalent full time workers ( 8 hours/day, 240 days/yr); this choice is due to the diversity of the several volunteers, not necessarily pledging to sustainability in their lives. Instead, the approach (b) is used for farmers. As detailed in footnote \#22 to Table 3, this is not referred to the actual salaries, self-reduced, but to the theoretical income for their jobs. The obtained value $(3.86 \mathrm{E}+16 \mathrm{sej} / \mathrm{yr})$ is right $49 \%$ of what would follow calculations through the approach (a), compatible with the ratio of the actual farmers' footprint and the average Italian footprint, thus suggesting a sound choice to correctly keep track of their contribution on a path toward sustainable living and cleaner production.

\subsection{On the significance of the sustainability indicators and novel UEVS}

\subsubsection{The emergy indicators}

The Emergy Yield Ratio (EYR) is the ratio between the total emergy yield output (U) and the emergy invested from main economy $(\mathrm{F})$; it measures a process' ability to make new emergy resources available by investing the ones that are already available (resource exploitation per unit of input from the outer economies). Here, values are perfectly in line with the reference small-scale organic horticultural production studied by Markussen et al. (2014). EYR values close to 1, like in this case, suggest that the local resources made available are relatively low compared to the inputs that are still imported, albeit the production is small, organic, and ligther than in other processes. Dramatically decreasing the need for the system's main inputs would not really change the situation, since imported inputs (F) are two to three orders of magnitude larger than local nonrenewables $(\mathrm{N})$ and renewables $(\mathrm{R})$. This aspect seems to confirm that agriculture is, after all, an anthropic activity, bringing at least part of the "weight" of contemporary human societies and economies as far as it is linked to (and reliant upon) them. The Emergy Investment Ratio (EIR) is the ratio between the imported emergy (F) and the local renewable and non renewable sources $(\mathrm{R}+\mathrm{N})$; it suggests whether a process is economically competitive in relation to the exploitation of local resources. Here, especially without labour and services, values are fairly encouraging. The Environmental Loading Ratio (ELR) compares the orders of magnitude of the emergy requirements from the outer economic systems and from local nonrenewable sources $(\mathrm{F}+\mathrm{N})$ with that of local renewables $(\mathrm{R})$; in other words, it measures the ecosystemic stress onto the local environment. Here, the ecosystemic stress is very high $(>>10)$, since relatively large flows are concentrated in a small area. The Emergy Sustainability Index (ESI), i.e. the ratio between EYR and ELR, measures economic and environmental performances altogether. In this study, ESI are actually quite poor, based on what stated above. The renewable emergy percentage (\%Ren) is $<1 \%$ both with and without labour and services, a little less than in Markussen et al. (2014) and La Rosa et al. (2008). Brown and Ulgiati (2001) define the renewable support area $\mathrm{SA}_{(\mathrm{r})}$ as "the result is the necessary area of the surrounding region that would be required if the economic activity were using solely renewable emergy inputs". For CSA Veneto, it would take 274 ha and 886 ha, respectively whether labour and services are excluded and included.

\subsubsection{The role of manure, and its consequences in the emergy indicators and UEVS}

Throughout the years, the agricultural systems that are cited here as references have undergone different approaches; in some cases, the UEV for organic manure is used after Bastianoni et al. (2001), in turn basing upon a Master's thesis from the early 1990s, i.e. before the emergy accounting method fully developed and 
matured, yielding a value that is two orders of magnitude smaller than the one used here (and that other authors use elsewhere). Emergy flows and indicators are necessarily affected. As noted in Markussen et al. (2014), manure is a co-product of meat and milk, so the entire input to livestock production is to be assigned to each of the products; as a proxy for its UEV, they use a combination of nitrogen, phosphorous, and potassium (as we also do, based on data from Spagnolo et al., 2020, whom also highlight the same issue, rooted in the overall unsustainability of livestock breeding). The results being poorer than in some studies, but similar to Markussen et al. (2014), ought to be read while keeping these considerations in mind.

\subsubsection{The new specific emergy values}

The specific emergy values for the organic horticultural produce at hand are $3.15 \mathrm{E}+12 \mathrm{sej} / \mathrm{kg}$ (without labour and services) and $1.02 \mathrm{E}+13 \mathrm{sej} / \mathrm{kg}$ (with $\mathrm{L} \& \mathrm{~S}$ ). Their orders of magnitude are comparable with results by Markussen et al. (2014) $)^{2}$, by Ortega et al. (2005) and Nakajima \& Ortega (2015) - who anyway use smaller UEVs for manure (2015) - and one order of magnitude smaller than data by La Rosa et al. (2008), anyway referred to an undemanding crop such as red orange; another undemanding product such as castorbean in an overall less emergy-intensive country still requires the same order of magnitude (Comar et al., 2004). From these comparative perspectives, the overall results from CSA Veneto look more encouraging than what emerges from the emergy sustainability indicators only. Furthermore, in this study transportation is also considered, and the small scale ( 0.45 ha versus various hectars) and young story might play a role as well.

4.3.4. The new transformities and the emergy per currency unit

The transformities have orders of magnitude of $10^{5}-10^{6} \mathrm{sej} / \mathrm{J}$. This can be also found for: castorbean (Comar et al., 2004), anyway a less demanding crop in a less demanding socio-economic context; similar vegetables (Markussen et al., 2014); and Ortega et al. (2005), again while keeping in mind that manure might be underestimated there. So, once again, results seems encouraging, especially since transport inputs are already accounted for in our study, and we are in the presence of a very small and young organic production project, with margins for improvement and optimisation after initial trial stages. Another promising result comes from the emergy per currency unit: for each euro averagely contributed to the project, the community members get two orders of magnitude more emergy than they would averagely get in Italy for other goods and services.

\subsection{Sensitivity analysis}

A sensitivity analysis can reveal the margins of uncertainty related to the emergy assessment at issue. This complies with the currently open debate within the emergist community (Ingwersen, 2010; Li et al., 2011; Yi \& Braham, 2015; Reza et al., 2013; Hudson \& Tilley, 2014), although not all authors include its assessment. In particular, sensitivity analyses are performed by changing the quantities of the driving inputs (raw amounts or UEVs) - typically, $10 \%$ and $20 \%$ - and evaluating the resulting effects on the total flows and indicators. In the study at hand, a $\pm 20 \%$ variation in the seedlings would yield a $\pm 4 \%$ change in the total emergy input without labour and services (U), a $\pm 1 \%$ change in the total emergy input with labour and services (ULS), and averagely a $\pm 2 \%$ in the emergy indicators $( \pm 1 \%$ in the ones with $L \& S)$. The same variation in the organic manure would imply $\pm 7 \%$ in U, $\pm 2 \%$ in ULS, and $\pm 4 \%$ in the indicators ( $\pm 2 \%$ in the ones with L\&S). A $\pm 20 \%$ variation in the labour input would instead cause a $\pm 8 \%$ in ULS and related indicators. Varying all the other inputs (and of course varying these three inputs by $\pm 10 \%$ only) would cause much smaller changes. Although the final changes partly absorb the initial variation, careful attention has been paid to the major inputs in order to ensure that reliable raw amounts are chosen, and suitable UEVs adopted from previous scientific literature. It is not a case that the main energy and material input, i.e. organic manure, and the main overall input, i.e. labour, have both undergone attentive choices as already detailed in Sections 4.2.1 and 4.3.2. This is meant to further strengthen the robustness of the results that are here presented.

\subsection{Improvement potentials for CSA Veneto}

The CSA Veneto was founded in 2017. Although this study refers to its first operational year (2018), the results are already encouraging. The present study is right oriented to support this horticultural venture to

\footnotetext{
${ }^{2}$ Assuming that they used the global emergy baseline $\mathrm{GEB}_{2005}$ by Campbell et al. (2005b); indeed, until the standardised agreements illustrated in Brown et al. (2016), several baselines were circulating, and not always declared by authors.
} 
improve its performances in terms of ecological sustainability. Looking at the results from Section 3, some considerations may follow toward possible improvements. First of all, purchasing the seedlings for many plants accounts for $20 \%$ of the energy and material inputs, and (with its associated services) $10 \%$ of the total emergy inputs, besides making the agricultural community dependent on something out of its control. Increasing the number of crops entirely grown in the field, starting from the seed, would therefore improve the overall performances of the horticultural production. As in Spagnolo et al. (2020), integrating farming with in-system livestock breeding and - we may add - other solutions to return the NPK nutrients to the soil (such as compost toilets, see e.g. Cristiano \& Falchetti, 2019) - would further improve the sustainability of CSA Veneto; in percentage, $37 \%$ of the energy and material inputs and $16 \%$ of the total emergy requirements are currently at stake in this sense. In practice, since several households who are part of the community live in a co-housing next to the fields, their returning the nutrients through sanitary facilities might represent a starting point in this direction. Savings may also derive from transportation. This might happen through a higher involvement of local inhabitants as members of the community, while possibly using the same assets (e.g. machinery) in adjacent fields, so as to reduce their impact per production unit: proximity and optimisation. The project could be replicated into new community-supported agricultural productions closer to the current distribution points, currently reaching - we can recall it here - 15 or even $27 \mathrm{~km}$ from the fields. A transport solution valid anyway would instead consist in light vehicles not requiring fuels, i.e. cargobikes, which would in turn require policy solutions for a safe use of the existing road infrastructures. CSA Veneto is already shifting from energy-intensive to labour-intensive agriculture. However, its machinery and related fuels still account for 19\% of its energy and material inputs: as per Rydberg \& Jansén (2002), replacing tractors with horses would bring net emergy benefits. Finally, labour-intensive farming would further decrease its requirements if the farmers' and volunteers' emergy per capita keep decreasing through virtuous lifestyles.

4.6. Learnings toward a sustainable, just, and resilient urban-rural local food production

The main features of CSA Veneto are connected to some social and economic dimensions that falls mostly beyond the scopes of the present emergy assessment. However, some lessons can be learnt. On the ecological side, the performances suggest a newborn process with margins for improvement: currently, the transformities and specific emergy values for the organic produce here investigated already compete with other vegetables, while exhibiting - compared to them - careful accounting devices aimed at not underestimating the actual requirements: namely, a higher UEV for nutrients and transportation toward final recipients already computed. The possible improvements able to decrease the emergy requirements, as suggested in Section 4.5, can also be applied to other productive systems. In particular, we can mention: (i) the return of valuable nutrients by the farming integration with livestock breeding (not necessarily for food purposes, see e.g. point iv) and human ejecta: closing the circle is after all among the foundations of the ecological principles (Commoner, 1971); (ii) the internal growing of seedlings, e.g. through seedbeds and incubators, in order to reduce the reliance upon nurseries (in addition to the related emergy requirements, a lesser dependence would also increase the resilience of a system, as illustrated in Cristiano et al., 2020, and Cristiano \& Gonella, 2020); (iii) the moltiplication of similar farming experiences in order to keep the scale small and the supply chain short, in particular not to need large machineries and long distances to be covered to deliver the produce; (iv) in a century when carbon emissions are accelerating climate change and nonrenewable resources are depleting, the shift from energy-intensive to labour-intensive agriculture seem promising, feasible (especially if matched with the small scale as per the previous point), and further improvable through animal labour (in turn also contributing to the first point of the present list); (v) the ecological benefits from an increased labour intensity would be boosted if the overall resource requirements per capita decrease, and this is not only linked to the individual choices (as per the reach of action of a single organisation, see Section 4.5) but also to societal shifts in general (in emergy terms, it is hard to track benefits with more labour use if the resources driving a labour unit keep increase as suggested by ever expanding economies; on the contrary, a rightsizing of the latter would imply ligher emergy requirements per capita and per currency unit, thus accelerating sustainability successes at all scales). Building upon Ortega et al. (2002), the emergy approach could represent a support toward a certification of sustainable organic food, and - we may add here - in a wider shift toward sustainable urbanrural food production in general. As an addendum to point (iv), Gasparatos (2011) maintains - also through emergy discourses - that the over reliance upon energy and (mainly imported) energy-intensive resources makes agricultural systems vulnerable. On the systemic side, a non-market, cooperative, and mutualist venture seems able to ensure enough food and mitigate inequalities in "normal" times, and to absorb shocks in "exceptional" circumstances. This is giving some households food during the ongoing health and economic crises. The pandemic might teach us something in terms of control over one basic livelihood in times of 
uncertainty, and - in the countryside and in cities - this has something to do with resilience (Cristiano, 2020). Currently, barriers seem mostly related to a cultural shift, and benefits involving several sustainability goals.

\subsection{Spatial and scale implications and prospects, between the local and the global spheres}

So far, the systemic and ecological assessment of the cooperative agricultural venture at hand suggest that strengths might come from several small projects, reinforncing the immaterial assets binding the members together, and decreasing the demand for machineries and fuel for transportation. In Section 4.8, the prospects toward and increased urban and rural resilience are also sketched. This is of course beyond the purposes of the present paper, but the re-localisation of food production (see e.g. Little et al., 2009) seems to exhibit a fair potential. If the possible expansion of the CSA model passes through its multiplication into many small projects rather than through an enlargement (with the local sphere more connected to material aspects, and the global one to immaterial links, see Cristiano et al., 2021), geographical implications seem to arise, and flexible local adaptations connected to local land, climate, societal, cultural, and economic aspects all to be addressed (as suggested e.g. in Kraehmer, 2018). Promising discourses are being made about imagining a sustainable and just food production compatible with societal issues, ecological concerns, and actual resource availability (Nelson \& Edwards, 2021). The present contribution can be read as a qualitative and quantitative contribution in that direction. Speaking of possible future developments in the valorisation of the outcomes of the present study, the spatial and geographic dynamics of agriculture, as treated by Lee \& Huang (2018), can also be read as a supporting tool. The increasing urbanisation and subsequent shrinkage and fragmentation of agricultural land have already been found to imply higher resource demands for farming (ibid.) could suggest that land, urban, and regional planning be involved too, in a transdisciplinary effort.

\section{Conclusions}

An Italy-based collaborative, not-for-sale, mutualist system for organic horticultural production is addressed, caring about social and ecological concerns altogether. An emergy assessment is performed, containing a focus on its systems diagram, thus offering both quantitative and qualitative insights. The main findings of this contribution can be summarised as follows.

- This producer-consumer cooperative system presents a unique systems diagram, in which (a) the yield is not sold, but distributed among members not necessarily funding the production; such a mutualist mechanism shows potentials to improve socio-economic sustainability and resilience, and is currently mitigating the effects of the ongoing health-related crisis by feeding affected households; (b) paid labour comes from members of the community, and voluntary work is also offered as a free input.

- The imported organic manure represents the major (37\%) among the energy and material inputs; the adopted UEV corrects potentially underestimating values used in several similar studies; other important inputs are the seedlings (20\%) the annual amortisation of the farming machines $(16 \%)$, and the fuel for the deliveries. If labour and services are also considered, these three inputs respectively become $11 \%, 6 \%, 5 \%$, and $4 \%(15 \%, 10 \%, 7 \%$, and $6 \%$ including their associated services), while labour stands out as the main inpus: paid labour (38\%) and voluntary work (8\%).

- The emergy sustainability indicators are comparable with those of similar processes assessed through similar procedures. Specific emergy and transformity values have the same order of magnitude of other studies; considering that some of these might underestimate some UEVs, that CSA Veneto has the tiniest fields (so assets are allocated to smaller amounts of output), and that the delivery to the final recipient is here already accounted for in the emergy assessment, results are encouraging.

- Multiple paths for a young agricultural venture to pursue further ecological savings are drafted, including actions for the internalisation of seedling tillage, a closed-loop nutrients' recovery, a stronger local attitude to use fuel-free vehicles for distribution (and to sprout into twin projects if needed), and a more marked shift from energy-intensive to labour-intensive cropping - considering fuel-free solutions also for the fields and making the labour itself requiring less resources through light living; decreasing the resource requirements would also improve the ecological sustainability and resilience.

- The present assessment might represent a benchmark to track the project's improvements year after year, and to possibly guide similar actions at the level of single producers and at higher levels too. At a producer's level, systems- and geobiophysics-based assessment tool can support decision-making in integrated sustainable choices. At a larger level, local policies might already improve the project by e.g. encouraging light cargo transportation by immaterial shifts to allow cycling in regional roads, and make it safe; for middle- and long-term changes (e.g. scaling up and replication), granted that local 
geographical and territorial features matter, decisions and policies could instead involve urban-rural interactions and planning, starting from the protection of fertile soil in and around towns and cities, so that agricultural fields are not fragmented among built environments, causing higher emergy costs.

- From the local to the global, this experience seems able to be exported in terms of differentiated replication, so as to shorten the supply chain and meet local material and immaterial diversity; on the contrary, the scale might grow so as to optimise the use of some fixed inputs (e.g. machinery), but may be limited by relational and ecological concerns: a looser community might make the mutualism fail, while the distances to be covered for the deliveries already present some issue.

- The exportability to other contexts would surely require considerations of local geographical, territorial, social, cultural, and economic featurs, and can be seen as a first stone of a wider route; together with the sole improvement of the existing project(s), urban and rural planning might also play a role: here, policies to make fuel-free vehicles run safely on existing infrastructure are sketched.

- Granted that improvements are possibile, as here suggested, the integration of the several spheres of sustainability - social, economic, and ecological - seem to propose this community-supported agriculture format as a model to address currently failing food and agriculture-related SGDs; if agronomic considerations are beyond the purposes of the present paper, the systems and emergy assessment track promising features in this direction, also in the light of crisis and post-crisis scenarios.

\section{Acknowledgements}

The author would like to gratefully thank the entire community of the CSA Veneto project; special thanks to: farmers Mr. Domenico Maffeo, Mr. Francesco Nordio, and Mr. Enrico Favaro; crop planning committee volunteers Ms. Doriana Giglioli, Mr. Alessandro Vesco, and Mr. Andrea Giubilato; bookkeeping volunteers Ms. Serenella Poletto, Mr. Enrico P., and Mr. Maurizio F. Many thanks also to Prof. Francesco Gonella for his feedback on the first draft of this manuscript.

\section{References}

Abel, T. (2010). Human transformities in a global hierarchy: Emergy and scale in the production of people and culture. Ecological modelling, 221(17), 2112-2117.

Agostinho, F., Ambrósio, L. A., \& Ortega, E. (2010). Assessment of a large watershed in Brazil using Emergy Evaluation and Geographical Information System. Ecological Modelling, 221(8), 1209-1220.

Ali, M., Marvuglia, A., Geng, Y., Robins, D., Pan, H., Song, X., ... \& Sun, H. (2019). Accounting emergybased sustainability of crops production in India and Pakistan over first decade of the 21 st century. Journal of Cleaner Production, 207, 111-122.

Almeida, C. M. V. B., Frugoli, A. D., Agostinho, F., Liu, G. Y., \& Giannetti, B. F. (2020). Integrating or Desintegrating agribusiness systems: Outcomes of emergy evaluation. Science of The Total Environment, 138733.

ARPAV - Agency for environmental protection and prevention of the Veneto region (2020). Dati ambientali. Section "Bollettini > Dati storici > Meteo-Idro ultimi anni". Online database. Retrieved October 25, 2020, from: https://www.arpa.veneto.it/dati-ambientali.

Artuzo, F. D., Allegretti, G., Santos, O. I. B., da Silva, L. X., \& Talamini, E. (2020). Emergy Unsustainability Index For Agricultural Systems Assessment: A Proposal Based On The Laws Of Thermodynamics. Science of The Total Environment, 143524.

Asgharipour, M. R., Shahgholi, H., Campbell, D. E., Khamari, I., \& Ghadiri, A. (2019). Comparison of the sustainability of bean production systems based on emergy and economic analyses. Environmental Monitoring and Assessment, 191(1), 2.

Bastianoni, S., Marchettini, N., Panzieri, M., \& Tiezzi, E. (2001). Sustainability assessment of a farm in the Chianti area (Italy). Journal of Cleaner Production, 9, 365-373.

Bastianoni, S., Pulselli, F. M., Castellini, C., Granai, C., Dal Bosco, A., \& Brunetti, M. (2007). Emergy evaluation and the management of systems towards sustainability: a response to Sholto Maud. Agriculture, Ecosystems \& Environment, 120(2-4), 472-474. 
Beck, T. B., Quigley, M. F., \& Martin, J. F. (2001). Emergy evaluation of food production in urban residential landscapes. Urban Ecosystems, 5(3), 187-207.

Brown, M.T., Buranakarn, V. (2003). Emergy indices and ratios for sustainable material cycles and recycle options. Resources, Conservation and Recycling 38(1), 1-22.

Brown, M.T., Campbell, D.E., De Vilbiss, C., \& Ulgiati, S. (2016). The geobiosphere emergy baseline: a synthesis. Ecological Modelling, 339, 92-95.

Brown, M. T., Protano, G., \& Ulgiati, S. (2011). Assessing geobiosphere work of generating global reserves of coal, crude oil, and natural gas. Ecological Modelling, 222(3), 879-887.

Brown, M.T., \& Ulgiati, S. (2001). Emergy measures of carrying capacity to evaluate economic investments. Population and Environment, 22 (5), 471-501.

Brown, M. T., \& Ulgiati, S. (2004). Energy quality, emergy, and transformity: HT Odum's contributions to quantifying and understanding systems. Ecological Modelling, 178(1-2), 201-213.

Brown, M.T., \& Ulgiati, S. (2016a). Assessing the global environmental sources driving the geobiosphere: A revised emergy baseline. Ecological Modelling, 339, 126-132.

Brown, M.T., \& Ulgiati, S. (2016b). Emergy assessment of global renewable sources. Ecological Modelling, 339, 148-156.

Campbell, D. E., Brandt-Williams, S. L., \& Meisch, M. E. (2005a). Environmental accounting using emergy: Evaluation of the state of West Virginia. US Environmental Protection Agency, Office of Research and Development, National Health and Environmental Effects Research Laboratory, Atlantic Ecology Division.

Campbell, D.E., \& Lu, H. (2014). Emergy evaluation of formal education in the United States: 1870 to 2011. Systems 2, 328-365.

Campbell, D. E., Brandt-Williams, S. L., \& Cai, T. (2005b). Current technical problems in emergy analysis. Emergy Synthesis, 3, 652.

Chen, D., Luo, Z., Webber, M., Chen, J., \& Wang, W. (2014). Emergy evaluation of the contribution of irrigation water, and its utilization, in three agricultural systems in China. Frontiers of Earth Science, $8(3), 325-337$.

Chen, G. Q., Jiang, M. M., Chen, B., Yang, Z. F., \& Lin, C. (2006). Emergy analysis of Chinese agriculture. Agriculture, Ecosystems \& Environment, 115(1-4), 161-173.

CIMAAV - Cassa per l'integrazione malattie e assistenze agricole varie (2019). Tabelle salariali impiegati e operai agricoli. 2018. https://www.cimaav.it/tabelle-salariali

Comar, V., Tilley, D., Felix, E., Turdera, M., \& Neto, M. C. (2004). Comparative eMergy evaluation of Castorbean (Ricinus Communis) production systems in Brazil an USA. In Proceedings of IV Biennial International Workshop "Advances in Energy Studies". Unicamp, Campinas, SP, Brazil (pp. 227-237).

Commoner, B. (1971). The Closing Circle: Nature, Man, and Technology.

Costanza, R. (1980). Embodied energy and economic valuation. Science, 210 (4475), 1219-1224.

Cristiano, S. (2020). Tavola vuota? Tabula rasa! Per un ripensamento urgente della forma e dei rifornimenti della città in una stagione di crisi e vulnerabilità: la priorità del cibo. Working papers, 1/2020.

Cristiano, S., Auriemma, M., Cacciari, P., Cervesato, M., Maffeo, D., Malgaretto, P., \& Nordio, F. (2021). Nourishing self-planned socioecological transformations. Glocal community supported agriculture in Veneto, Italy. In: Nelson, A., \& Edwards, F. (Eds.). Food for Degrowth: Perspectives and Practices. Routledge.

Cristiano, S., \& Falchetti, C. (2019). Vernacular wisdom as a path towards ecologically sustainable housing and settlements: participatory design and building to rehabilitate local adobe brick constructions in El Salvador. Journal of World Architecture, 4(1).

Cristiano, S., \& Gonella, F. (2019). To build or not to build? Megaprojects, resources, and environment: an emergy synthesis for a systemic evaluation of a major highway expansion. Journal of Cleaner Production, 223, 772-789.

Cristiano, S., Gonella, F., Nannini, E., \& Spagnolo, S. (2018). Care before business: on the potential of emergy analysis to address the sustainability of not-for-profit systems. $10^{\text {th }}$ Biennial Emergy Research Conference. Emergy Synthesis 10 (Online poster). DOI: 10.13140/RG.2.2.36375.01443

Cristiano, S., \& Gonella, F. (2020). 'Kill Venice': a systems thinking conceptualisation of urban life, economy, and resilience in tourist cities. Humanities and Social Sciences Communications, 7(1), 1-13.

Cristiano, S., Ulgiati, S., \& Gonella, F. (forthcoming). Systemic sustainability and resilience assessment of health systems, addressing global societal priorities: learnings from a top nonprofit hospital in a bioclimatic building in Africa. 
Cristiano, S., Zucaro, A., Liu, G., Ulgiati, S., \& Gonella, F. (2020). On the systemic features of urban systems. A look at material flows and cultural dimensions to address post-growth resilience and sustainability. Frontiers in Sustainable Cities, 2(12).

De Barros, I., Blazy, J. M., Rodrigues, G. S., Tournebize, R., \& Cinna, J. P. (2009). Emergy evaluation and economic performance of banana cropping systems in Guadeloupe (French West Indies). Agriculture, Ecosystems \& Environment, 129(4), 437-449.

De Vilbiss, C., Brown, M.T. (2015). New method to compute the emergy of crustal minerals. Ecological Modelling, 315, 108-115.

Della Vedova, B., Bellani, S., Pellis, G., Squarci, P. (2001). Deep temperatures and surface heat flow distribution. In: Anatomy of an orogen: the Apennines and adjacent Mediterranean basins (pp. 65-76). Springer Netherlands.

Dong, X., Zhang, Y., Cui, W., Xun, B., Yu, B., Ulgiati, S., \& Zhang, X. (2011). Emergy-based adjustment of the agricultural structure in a low-carbon economy in Manas County of China. Energies, 4(9), 14281442.

Fahd, S., Fiorentino, G., Mellino, S., \& Ulgiati, S. (2012). Cropping bioenergy and biomaterials in marginal land: the added value of the biorefinery concept. Energy, 37, 79-93.

FAO - Food and Agriculture Organization of the United Nations (2003). Food energy - methods of analysis and conversion factors. Report of a Technical Workshop, Rome, 3-6 December 2002. FAO, Rome.

FAO - Food and Agriculture Organization of the United Nations (2020a). Sustainable Development Goals. [http://www.fao.org/sustainable-development-goals/en/, retrieved November 2020]

FAO - Food and Agriculture Organization of the United Nations (2020b). Tracking progress on food and agriculture-related SDG indicators 2020. A report on the indicators under FAO custodianship.

Ferraro, D. O., \& Benzi, P. (2015). A long-term sustainability assessment of an Argentinian agricultural system based on emergy synthesis. Ecological Modelling, 306, 121-129.

Gasparatos, A. (2011). Resource consumption in Japanese agriculture and its link to food security. Energy Policy, 39(3), 1101-1112.

Ghisellini, P., Zucaro, A., Viglia, S., \& Ulgiati, S. (2014). Monitoring and evaluating the sustainability of Italian agricultural system. An emergy decomposition analysis. Ecological Modelling, 271, 132-148.

Giannetti, B. F., Ogura, Y., Bonilla, S. H., \& Almeida, C. M. V. B. (2011). Accounting emergy flows to determine the best production model of a coffee plantation. Energy Policy, 39(11), 7399-7407.

Gibson-Graham, J. K. (2006). A Postcapitalist Politics. University of Minnesota Press. Minneapolis, USA.

Global Footprint Network, York Univerisy, \& Footprint Data Foundation (2020). Ecological Fooprint. Country Data. Year 2019. https://data.footprintnetwork.org/\#/

Gomiero, T., Paoletti, M. G., \& Pimentel, D. (2008). Energy and environmental issues in organic and conventional agriculture. Critical Reviews in Plant Sciences, 27(4), 239-254.

Gonella, F., Brocca, G., Cristiano, S., Khoury, N., Salmistraro, G., \& Spagnolo, S. (2019). When Systemic Sustainability is an Everyday Struggle: An Emergy-Based Analysis of a Dog Shelter. In: Brown, M.T., Sweeney, S., Campbell, D.E., Huang, S., Rydberg, T., \& Ulgiati, S. (Eds) (2019). Emergy Synthesis 10: Theory and Applications of the Emergy Methodology. Proceedings of the $10^{\text {th }}$ Biennial Emergy Conference. Center for Environmental Policy, University of Florida, Gainesville.

González-Mejía, A. M., \& Ma, X. C. (2017). The emergy perspective of sustainable trends in Puerto Rico from 1960 to 2013. Ecological Economics, 133, 11-22.

Houshyar, E., Wu, X. F., \& Chen, G. Q. (2018). Sustainability of wheat and maize production in the warm climate of southwestern Iran: an emergy analysis. Journal of Cleaner Production, 172, 2246-2255.

Hudson, A., \& Tilley, D.R. (2014). Assessment of uncertainty in emergy evaluations using Monte Carlo simulations. Ecological Modelling, 271, 52-61.

Ingwersen, W.W. (2010). Uncertainty characterization for emergy values. Ecological Modelling, 221, 445452.

ISTAT - Istituto Nazionale di Statistica (Italian National Statistics Institute) (2012). $6^{\circ}$ Censimento Generale dell'Agricoltura $\left(6^{\text {th }}\right.$ General Census of Italian Agriculture). https://www.istat.it/it/archivio/66591

Jafari, M., Asgharipour, M. R., Ramroudi, M., Galavi, M., \& Hadarbadi, G. (2018). Sustainability assessment of date and pistachio agricultural systems using energy, emergy and economic approaches. Journal of Cleaner Production, 193, 642-651.

Jaklič, T., Juvančič, L., Kavčič, S., \& Debeljak, M. (2014). Complementarity of socio-economic and emergy evaluation of agricultural production systems: The case of Slovenian dairy sector. Ecological Economics, 107, 469-481. 
Jiang, M. M., Chen, B., Zhou, J. B., Tao, F. R., Li, Z., Yang, Z. F., \& Chen, G. Q. (2007). Emergy account for biomass resource exploitation by agriculture in China. Energy policy, 35(9), 4704-4719.

Kamp, A., Morandi, F., \& Østergård, H. (2016). Development of concepts for human labour accounting in Emergy Assessment and other Environmental Sustainability Assessment methods. Ecological Indicators, 60, 884-892.

Kitzes, J., Peller, A., Goldfinger, S., \& Wackernagel, M. (2007). Current Methods for Calculating National Ecological Footprint Accounts. Science for Environment \& Sustainable Society, 4 (1), 1-9.

Kraehmer, K. (2018). Geography matters: ideas for a degrowth spatial planning paradigm - on Xue and Vansintjan II. In: Nelson, A., \& Schneider, F. (Eds.). Housing for Degrowth. Principles, models, challenges and opportunities. Routledge, London, 217-223.

Kuczuk, A. (2016). Cost-, Cumulative Energy-and Emergy Aspects of Conventional and Organic Winter Wheat (Triticum aestivum L.) Cultivation. Journal of Agricultural Science, 8(4), 140-155.

La Rosa, A. D., Siracusa, G., \& Cavallaro, R. (2008). Emergy evaluation of Sicilian red orange production. A comparison between organic and conventional farming. Journal of Cleaner Production, 16(17), 19071914.

Lamb, G. (1994). Community supported agriculture. Threefold Review, 11, 39-43.

Lee, H. N., Lee, W. K., \& Kim, J. G. (2005). Emergy analysis of Korean agriculture. Korean Journal of Environmental Agriculture, 24(2), 169-179.

Lee, Y. C., \& Huang, S. L. (2018). Spatial emergy analysis of agricultural landscape change: Does fragmentation matter?. Ecological Indicators, 93, 975-985.

Lefroy, E., \& Rydberg, T. (2003). Emergy evaluation of three cropping systems in southwestern Australia. Ecological Modelling, 161(3), 195-211.

Lewandowska-Czarnecka, A., Buller, L. S., Nienartowicz, A., \& Piernik, A. (2019). Energy and emergy analysis for assessing changes in Polish agriculture since the accession to the European Union. Ecological Modelling, 412, 108819.

Little, J., Ilbery, B., \& Watts, D. (2009). Gender, consumption and the relocalisation of food: A research agenda. Sociologia Ruralis, 49(3), 201-217.

Li, L., Lu, H., Campbell, D.E., \& Ren, H. (2011). Methods for estimating the uncertainty in emergy table-form models. Ecological Modelling, 222, 2615-2622.

Liu, Z., Wang, Y., Geng, Y., Li, R., Dong, H., Xue, B., ... \& Wang, S. (2019). Toward sustainable crop production in China: An emergy-based evaluation. Journal of Cleaner Production, 206, 11-26.

Lou, B., Qiu, Y., \& Ulgiati, S. (2015). Emergy-based indicators of regional environmental sustainability: a case study in Shanwei, Guangdong, China. Ecological Indicators, 57, 514-524.

Lu, H., Bai, Y., Ren, H., \& Campbell, D. E. (2010). Integrated emergy, energy and economic evaluation of rice and vegetable production systems in alluvial paddy fields: implications for agricultural policy in China. Journal of Environmental Management, 91(12), 2727-2735.

Lu, H. F., Kang, W. L., Campbell, D. E., Ren, H., Tan, Y. W., Feng, R. X., ... \& Chen, F. P. (2009). Emergy and economic evaluations of four fruit production systems on reclaimed wetlands surrounding the Pearl River Estuary, China. Ecological Engineering, 35(12), 1743-1757.

Lupinacci, D. M., \& Bonilla, S. H. (2018). Exploring approaches and dimensions of human transformity through an educational case. Ecological Modelling, 368, 336-343.

Lynch, D. H., MacRae, R., \& Martin, R. C. (2011). The carbon and global warming potential impacts of organic farming: does it have a significant role in an energy constrained world?. Sustainability, 3(2), 322-362.

Lyons, K., Richards, C., Desfours, L., \& Amati, M. (2013). Food in the city: urban food movements and the (re)-imagining of urban spaces. Australian Planner, 50(2), 157-163.

Maass Wolfenson, K.D. (2013). Coping with the food and agriculture challenge: smallholders' agenda. Preparations and outcomes of the 2012 United Nations Conference on Sustainable Development $($ Rio +20). Natural Resources Management and Environment Department. Food and Agriculture Organization of the United States. Rome, April 2013, revised July 2013.

Markussen, M. V., Kulak, M., Smith, L. G., Nemecek, T., \& Østergård, H. (2014). Evaluating the sustainability of a small-scale low-input organic vegetable supply system in the United Kingdom. Sustainability, 6(4), 1913-1945.

Martin, J. F., Diemont, S. A., Powell, E., Stanton, M., \& Levy-Tacher, S. (2006). Emergy evaluation of the performance and sustainability of three agricultural systems with different scales and management. Agriculture, Ecosystems \& Environment, 115(1-4), 128-140. 
McDougall, R., Kristiansen, P., \& Rader, R. (2019). Small-scale urban agriculture results in high yields but requires judicious management of inputs to achieve sustainability. Proceedings of the National Academy of Sciences, 116(1), 129-134.

Meadows, D. H. (2008). Thinking in Systems: A primer. Chelsea Green Publishing. Chelsea, Vermont, USA.

Merrill, A.L., \& Watt, B.K. Energy value of foods: Basis and derivation. United States Department of Agriculture. Washington DC.

Miller, B.I. (1964). A study of the filling of Hurricane Donna (1960) over land. Monthly Weather Review, 92(9), 389-406.

Nakajima, E. S., \& Ortega, E. (2015). Exploring the sustainable horticulture productions systems using the emergy assessment to restore the regional sustainability. Journal of Cleaner Production, 96, 531-538.

Nelson, A., \& Edwards, F. (Eds.). (2021). Food for Degrowth: Perspectives and Practices. Routledge.

Odum, H.T. (1967). Energetics of Food Production. The World Food Problem, Report of the President's Science Advisory Committee, Panel on World Food Supply, Vol. 3, The Whitehouse, pp. 55-94.

Odum, H.T. (1988). Self-organization, transformity, and information. Science, 242, 1132-1139.

Odum, H.T. (1994). Ecological and General Systems: An Introduction to Systems Ecology. University Press of Colorado, Niwot, CO.

Odum, H.T. (1996). Environmental accounting: emergy and environmental decision making. John Wiley and Sons, New York, NY.

Ortega, E., Anami, M., \& Diniz, G. (2002). Certification of food products using emergy analysis. In Proceedings of III International Workshop Advances in Energy Studies (pp. 227-237).

Ortega, E., Cavalett, O., Bonifácio, R., \& Watanabe, M. (2005). Brazilian soybean production: emergy analysis with an expanded scope. Bulletin of Science, Technology \& Society, 25(4), 323-334.

Park, Y. S., Egilmez, G., \& Kucukvar, M. (2016). Emergy and end-point impact assessment of agricultural and food production in the United States: A supply chain-linked Ecologically-based Life Cycle Assessment. Ecological Indicators, 62, 117-137.

Patrizi, N., Niccolucci, V., Castellini, C., Pulselli, F. M., \& Bastianoni, S. (2018). Sustainability of agrolivestock integration: Implications and results of Emergy evaluation. Science of The Total Environment, $622,1543-1552$.

Pellicer-Sifres, V., Belda-Miquel, S., López-Fogués, A., \& Boni Aristizabal, A. (2017). Grassroots social innovation for human development: An analysis of alternative food networks in the city of Valencia (Spain). Journal of Human Development and Capabilities, 18(2), 258-274.

Pizzigallo, A. C. I., Granai, C., \& Borsa, S. (2008). The joint use of LCA and emergy evaluation for the analysis of two Italian wine farms. Journal of Environmental Management, 86(2), 396-406.

Purcell, M., \& Tyman, S. K. (2015). Cultivating food as a right to the city. Local Environment, 20(10), 11321147.

Reza, B., Sadiq, R., \& Hewage, K. (2013). A fuzzy-based approach for characterization of uncertainties in emergy synthesis: an example of paved road system. Journal of Cleaner Production, 59, 99-110.

Ricciardi, V., Ramankutty, N., Mehrabi, Z., Jarvis, L., \& Chookolingo, B. (2018). How much of the world's food do smallholders produce?. Global Food Security, 17, 64-72.

Rótolo, G.C., Francis, C., Craviotto, R.M., Viglia, S., Pereyra, A., \& Ulgiati, S. (2015). Time to re-think the GMO revolution in agriculture. Ecological Informatics, 26, 35- 49.

Rótolo, G.C., Francis, C., Craviotto, R.M., \& Ulgiati, S. (2015). Environmental assessment of maiz production alternatives: traditional, intensive and GMO- based cropping patterns. Ecological Indicators, 57, 48-60.

Rydberg, T., \& Haden, A. C. (2006). Emergy evaluations of Denmark and Danish agriculture: Assessing the influence of changing resource availability on the organization of agriculture and society. Agriculture, Ecosystems \& Environment, 117(2-3), 145-158.

Rydberg, T., \& Jansén, J. (2002). Comparison of horse and tractor traction using emergy analysis. Ecological Engineering, 19(1), 13-28.

Scott, S., Si, Z., Schumilas, T., \& Chen, A. (2018). Organic food and farming in China: Top-down and bottomup ecological initiatives. Routledge.

Shah, S. M., Liu, G., Yang, Q., Wang, X., Casazza, M., Agostinho, F., ... \& Giannetti, B. F. (2019). Emergybased valuation of agriculture ecosystem services and dis-services. Journal of Cleaner Production, 239, 118019.

Smith, L. G., Williams, A. G., \& Pearce, B. D. (2015). The energy efficiency of organic agriculture: A review. Renewable agriculture and Food systems, 30(3), 280. 
Spagnolo, S., Chinellato, G., Cristiano, S., Zucaro, A., \& Gonella, F. (2020). Sustainability assessment of bioenergy at different scales: An emergy analysis of biogas power production. Journal of Cleaner Production, 277, 124038.

Su, Y., He, S., Wang, K., Shahtahmassebi, A. R., Zhang, L., Zhang, J., ... \& Gan, M. (2020). Quantifying the sustainability of three types of agricultural production in China: An emergy analysis with the integration of environmental pollution. Journal of Cleaner Production, 252, 119650.

Sweeney, S., Cohen, M. J., King, D., \& Brown, M. T. (2007). Creation of a global emergy database for standardized national emergy synthesis. Emergy Synthesis, 4, 483-497.

Tao, J., Fu, M., Zheng, X., Zhang, J., \& Zhang, D. (2013). Provincial level-based emergy evaluation of crop production system and development modes in China. Ecological Indicators, 29, 325-338.

Ulgiati, S., \& Brown, M. T. (2012). Labor and services. In Proceedings of the $7^{\text {th }}$ biennial emergy conference. Center for Environmental Policy, University of Florida, Gainesville (pp. 557-562).

Ulgiati, S., \& Brown, M.T. (2014). Labor and services as information carriers in emergy-LCA accounting. Journal of Environmental Accounting and Management, 2 (2), 163-70.

Ulgiati, S., Odum, H.T., \& Bastianoni, S. (1992). Emergy analysis of Italian agricultural system. The role of energy quality and environmental inputs. In: Bonati, L., et al. (Eds.). Trends in ecological physical chemistry. Elsevier, Amsterdam, 187-215.

UNI - Ente nazionale italiano di unificazione (Italian national standardisation organisation) (1983). 84771:1983 - Solar energy. Calculation of energy gains for building applications. Evaluation of radiant received energy.

United Nations (2015). Transforming our world: the 2030 Agenda for Sustainable Development. [https://sustainabledevelopment.un.org/post2015/transformingourworld, retrieved November 2020]

USDA - United States Department of Agriculture (2019). Food and nutrient database for dietary studies. 20172018. Agricultural Research Service. https://www.ars.usda.gov/northeast-area/beltsville-mdbhnrc/beltsville-human-nutrition-research-center/food-surveys-research-group/docs/fndds-factsheets/

Volz, P., Weckenbrock, P., Nicolas, C., Jocelyn, P., \& Dezsény, Z. (2016). Overview of Community Supported Agriculture in Europe. Aubagne, France: European CSA Research Group.

Wackernagel, M., \& Rees, W. (1996). Our ecological footprint: reducing human impact on the earth. New Society Publishers, Philadelphia.

Wang, J. Y., Xue, D. Q., Tian, X. P., \& Chen, Y. C. (2007). Emergy analysis of agroecosystems in Shandong Province of China. Chinese Journal of Ecology, 5.

Wang, Q., Ma, Z., Ma, Q., Liu, M., Yuan, X., Mu, R., ... \& Wang, S. (2019). Comprehensive evaluation and optimization of agricultural system: An emergy approach. Ecological Indicators, 107, 105650.

Wang, X., Shen, J., \& Zhang, W. (2014). Emergy evaluation of agricultural sustainability of Northwest China before and after the grain-for-green policy. Energy Policy, 67, 508-516.

Wei, X. M., Chen, B., Qu, Y. H., Lin, C., \& Chen, G. Q. (2009). Emergy analysis for 'Four in One'peach production system in Beijing. Communications in Nonlinear Science and Numerical Simulation, 14(3), 946-958.

Wood, R., Lenzen, M., Dey, C., \& Lundie, S. (2006). A comparative study of some environmental impacts of conventional and organic farming in Australia. Agricultural systems, 89(2-3), 324-348.

Yi, H., \& Braham, W.W. (2015). Uncertainty characterization of building emergy analysis (BEmA). Building and Environment, 92, 538-558.

Zhai, X., Zhao, H., Guo, L., Finch, D. M., Huang, D., Liu, K., ... \& Xie, S. (2018). The emergy of metabolism in the same ecosystem (maize) under different environmental conditions. Journal of Cleaner Production, 191, 233-239.

Zhan, J., Zhang, F., Chu, X., Liu, W., \& Zhang, Y. (2019). Ecosystem services assessment based on emergy accounting in Chongming Island, Eastern China. Ecological Indicators, 105, 464-473.

Zhang, L. X., Song, B., \& Chen, B. (2012). Emergy-based analysis of four farming systems: insight into agricultural diversification in rural China. Journal of Cleaner Production, 28, 33-44.

Zhang, X. H., Zhang, R., Wu, J., Zhang, Y. Z., Lin, L. L., Deng, S. H., ... \& Peng, H. (2016). An emergy evaluation of the sustainability of Chinese crop production system during 2000-2010. Ecological Indicators, 60, 622-633. 